\title{
EPIDEMI PENYAKIT BUSUK PANGKAL BATANG LADA PADA KONDISI LINGKUNGAN YANG BERVARIASI
}

\author{
La Ode Santiaji Bande ${ }^{1}$ Bambang Hadisutrisno ${ }^{2}$, Susamto Somowiyarjo², \\ \& Bambang Hendro Sunarminto ${ }^{2}$
}

\author{
'Jurusan Agroteknologi Fakultas Pertanian Universitas Halu Oleo Kendari \\ Jalan M.T Haryono, Anduonou, Kendari, Sulawesi Tenggara 93132 \\ ${ }^{2}$ Fakultas Pertanian Universitas Gadjah Mada Yogyakarta \\ E-mail: 1s.bande@yahoo.co.id
}

\begin{abstract}
Foot rot disease epidemic on black pepper in variety of environmental conditions. The foot rot disease on black pepper caused by Phytophthora capsici Leonian, is often destructive to farmers of black pepper. This research aims to study the infection rate and the pattern of development of the black pepper foot rot disease in various condition of the environment. The research was conducted in the areas of black pepper cultivation in the Ultisol and Entisol soils. In each location plots were set with few $(<25 \%)$ and abundant $(>75 \%)$ weeds. Variable observed was disease incidence. The data were used to analyze model of development of the black pepper foot rot disease and infection rate. Results of the research showed that the model of development of the black pepper foot rot disease was not affected by soil type, but the type of soil affected the infection rate. At the pepper plantation with abundance of weeds, the disease development followes Gompertz model. At the plantation with few weeds, however the disease developed in a logistic model. The rate of disease infection on the black pepper plant with abundant weeds lower compared with those with few weeds.
\end{abstract}

Key words: epidemic, foot rot disease, infection rate, pattern of development disease

\begin{abstract}
ABSTRAK
Epidemi penyakit busuk pangkal batang lada pada kondisi lingkungan yang bervariasi. Penyakit busuk pangkal batang lada yang disebabkan oleh Phytophthora capsici Leonian telah menjadi ancaman bagi petani lada. Penelitian ini bertujuan untuk mengetahui model perkembangan dan laju infeksi penyakit busuk pangkal batang lada pada kondisi lingkungan yang bervariasi. Penelitian ini dilaksanakan di daerah sentra pertanaman lada dengan jenis tanah Ultisol dan Entisol. Masingmasing lokasi dibuat plot pengamatan pada kondisi lahan yang gulmanya banyak $(>75 \%)$ dan gulmanya sedikit $(<25 \%)$. Variabel yang diamati yaitu intensitas penyakit (yang diamati tiap 2 minggu). Data tersebut digunakan untuk menganalisis model perkembangan penyakit dan laju infeksi penyakit busuk pangkal batang lada. Hasil penelitian menunjukkan bahwa model perkembangan penyakit busuk pangkal batang lada tidak dipengaruhi oleh jenis tanah tetapi jenis tanah mempengaruhi laju infeksi penyakit. Pada pertanaman lada dengan gulma banyak, model perkembangan penyakit adalah Gompertz, dan pada lahan dengan gulma sedikit, model perkembangan penyakitnya adalah logistik. Laju infeksi penyakit lebih rendah pada jenis tanah Ultisol dibanding pada tanah Entisol. Pertanaman lada yang gulmanya banyak mempunyai laju infeksi yang lebih rendah dibandingkan dengan pertanaman lada yang gulmanya sedikit.
\end{abstract}

Kata kunci: epidemi, laju infeksi, model perkembangan penyakit, penyakit busuk pangkal batang

\section{PENDAHULUAN}

Lada (Piper nigrum) banyak diusahakan dalam bentuk perkebunan rakyat yang pengusahaannya masih menerapkan teknik budidaya sederhana (Yuhono, 2007). Lada selain terdapat di Lampung dan Bangka-Belitung, juga telah menyebar di Sulawesi Selatan, Sulawesi Tenggara, Kalimantan Barat, Kalimantan Tengah, Kalimantan Timur, Kalimantan Selatan, Bengkulu, Sumatera Selatan, Jawa Barat, Jawa Tengah, dan Jawa
Timur (Balittri, 2009). Budidaya lada khususnya di Provinsi Sulawesi Tenggara banyak diusahakan di lahan kering dengan tingkat kesuburan tanah yang rendah dengan input pemupukan yang sangat terbatas bahkan ada yang masih mengandalkan kesuburan alami.

Penyakit utama pada lada saat ini adalah busuk pangkal batang lada yang disebabkan oleh Phytophthora capsici (Manohara et al., 2005; Bande et al., 2011). Epidemi penyakit ini terus meningkat dan mengancam pertanaman lada di berbagai daerah di 
Indonesia. Harga lada yang fluktuatif menyebabkan petani tidak memelihara tanamannya dengan baik dan membiarkan tanamannya tumbuh dalam kondisi tidak sehat (Wahyuno, 2009). Tanaman yang tidak terawat dengan baik menyebabkan pertanaman tersebut menjadi rentan terhadap infeksi $P$. capsici. Penyebaran patogen dari penyakit ini di lapangan dapat terbawa oleh aliran permukaan, gerakan kemotaksis zoospora, pertemuan akar sakit dengan akar sehat, atau peralatan pertanian yang terkontaminasi (Manohara et al., 2005; Benson et $a l ., 2006)$. Tanaman yang rentan dan penularan patogen yang memiliki banyak cara menjadi pendukung terjadinya epidemi penyakit busuk pangkal batang lada secara cepat.

Perkembangan dalam bidang epidemiologi telah memunculkan berbagai analisis dalam model perkembangan penyakit sesuai dengan perubahan kondisi inang, patogen, dan lingkungan. Untuk menentukan model yang tepat diperlukan perbandingan model epidemi penyakit (Berger, 1981). Epidemi penyakit tumbuhan di alam merupakan interaksi yang kompleks dan dinamis dari tiga faktor utamanya yaitu patogen, inang, dan lingkungan (Zadoks \& Schein, 1979). Epidemi penyakit tumbuhan berkembang dalam skala ruang dan waktu yang dinamis. Pemahaman yang kompleks dari faktor-faktor yang berpengaruh dalam skala ruang dan waktu tersebut akan menjadi dasar pendugaan terhadap terjadinya epidemi penyakit dalam mendukung keberhasilan pengelolaan penyakit (Milgroom \& Peever, 2003).

Variasi lingkungan agroekosistem perkebunan lada diduga mempengaruhi terjadinya epidemi penyakit busuk pangkal batang lada.Variasi lingkungan tersebut dapat berupa variasi jenis tanah dan penutupan gulma yang secara langsung maupun tidak langsung mempengaruhi penularan $P$. capsici di pertanaman lada. Oleh karena itu penelitian tentang model perkembangan dan laju infeksi penyakit busuk pangkal batang lada pada jenis tanah dan penutupan gulma yang bervariasi menjadi penting untuk dilakukan.

Penelitian ini bertujuan untuk mengetahui model perkembangan dan laju infeksi penyakit penyakit busuk pangkal batang lada pada kondisi lingkungan yang bervariasi dalam hal jenis tanah dan penutupan gulmanya.

\section{METODE PENELITIAN}

Tempat dan Waktu. Penelitian ini dilaksanakan di daerah pertanaman lada Kabupaten Konawe Selatan dan Kabupaten Konawe, Provinsi Sulawesi Tenggara.
Penelitian ini berlangsung mulai Maret 2010 sampai November 2011.

Penentuan Daerah Pengamatan. Penentuan daerah untuk pengamatan didasarkan pada perbedaan jenis tanah dan penutupan gulma yang informasinya diperoleh dari hasil survei pendahuluan. Kecamatan Konda di Kabupaten Konawe Selatan mewakili jenis tanah Ultisol dan Kecamatan Wawotobi di Kabupaten Konawe mewakili jenis tanah Entisol. Lokasi untuk pembuatan plot pengamatan ditentukan berdasarkan: sentra pertanaman lada (hamparan lebih 5 ha), kejadian penyakit kurang dari $15 \%$, dan luas plot pengamatan lebih dari 0,25 ha. Pada tiap lokasi pengamatan terpilih, dibuat enam petak pengamatan (tiga petak pada kebun yang penutupan gulmanya sedikit (penutupannya $<25 \%$ ) dan tiga petak lainnya pada kebun yang penutupan gulmanya banyak (penutupannya $>75 \%$ )). Tingkat penutupan gulma ditentukan secara visual. Setiap plot terdiri atas 100 tanaman lada. Tanaman yang dijadikan sampel yaitu lada yang telah berumur 6-7 tahun.

Pengamatan. Pengamatan kejadian penyakit dilakukan tiap dua minggu sekali. Data kejadian penyakit yang diperoleh setiap 2 minggu digunakan untuk menghitung proporsi penyakit yang kemudian digunakan untuk penentuan model perkembangan penyakit busuk pangkal batang lada. Proporsi penyakit di hitung dengan rumus:

dengan:

$$
\mathrm{P}=\frac{\mathrm{a}}{\mathrm{b}}
$$

$\mathrm{P}=$ proporsi penyakit

$\mathrm{a}=$ jumlah tanaman lada yang layu

$\mathrm{b}=$ Jumlah total tanaman lada sampel yang diamati

Untuk mengetahui model perkembangan penyakit busuk pangkal batang lada yang tepat, dilakukan uji ketepatan model atau uji kebaikan suai (goodness of fit) perkembangan penyakit pada tiga model yang paling banyak digunakan yaitu monomolekular, logistik, dan Gompertz (Neher \& Campbell, 1992; Rivai, 2009). Pemilihan model melalui transformasi data proporsi penyakit (x) yang telah dikumpulkan, masing-masing ke dalam $\ln (1 /(1-\mathrm{x})$ untuk model monomolekular, $\ln \{\mathrm{x} /(1-$ $\mathrm{x})\}$ untuk model logistik, dan $\{-\ln (-\ln \mathrm{x})\}$ untuk model Gompertz. Data baru ini diregresi secara linier terhadap waktu (t) perkembangan penyakit tersebut. Selanjutnya dilakukan uji kebaikan suai (goodness of fit) model tersebut dengan melihat koefisien determinasi $\left(R^{2}\right)$ dan kuadrat tengah galat (KTG). Model terbaik dipilih dengan syarat koefisien determinasi $\left(\mathrm{R}^{2}\right)$ yang terbesar 
dan kuadrat tengah galat (KTG) yang kecil (Campbell et al., 1984; Rivai, 2009). Kurva model perkembangan penyakit digambar dengan menggunakan program KaleidaGraph 4.0.

Selain itu, data tersebut digunakan juga untuk perhitungan laju infeksi atau $\mathrm{r}$ (infection rate). Perhitungan laju infeksi didasarkan pada hasil pemilihan model perkembangan penyakit dengan menggunakan rumus:

Model monomolekular:

$$
\mathrm{r}_{\mathrm{m}}=\frac{1}{\mathrm{t}}\left(\ln \frac{1}{1-\mathrm{x}_{\mathrm{t}}}-\ln \frac{1}{1-\mathrm{x}_{0}}\right) \text { per unit per waktu }
$$

Model logistik:

$$
\mathrm{r}_{1}=\frac{1}{\mathrm{t}}\left(\ln \frac{\mathrm{x}_{\mathrm{t}}}{1-\mathrm{x}_{\mathrm{t}}}-\ln \frac{\mathrm{x}_{0}}{1-\mathrm{x}_{\mathrm{t}}}\right) \text { per unit waktu }
$$

Model Gompertz:

$$
\mathrm{r}_{\mathrm{g}}=\frac{1}{\mathrm{t}}-\ln \left\{-\ln \left(\mathrm{x}_{\mathrm{t}}\right)\right\}+\ln \left\{-\ln \left(\mathrm{x}_{0}\right)\right\} \text { per unit waktu }
$$

dengan:

$\mathrm{x}_{\mathrm{t}}=$ proporsi penyakit pada waktu $\mathrm{r}$

$\mathrm{x}_{0}=$ proporsi penyakit pada awal pengamatan $(\mathrm{t}=0)$

$\mathrm{t}=$ waktu

$\mathrm{r}$ = laju infeksi penyakit

\section{HASIL DAN PEMBAHASAN}

Hasil penelitian menunjukkan bahwa kejadian penyakit busuk pangkal batang lada dari waktu ke waktu terus meningkat (Tabel 1 dan Tabel 2). Kondisi lingkungan pertanaman lada menentukan model perkembangan penyakit busuk pangkal batang lada. Dalam penelitian ini penyakit busuk pangkal batang lada yang disebabkan oleh Phytophthora capsici mempunyai lebih dari satu model perkembangan penyakit. Dengan demikian penentuan model perkembangan penyakit busuk pangkal batang lada dalam satu model perkembangan penyakit agak menyulitkan. Kesulitan yang sama juga dilaporkan oleh MacKenzie et al. (1983) bahwa penyakit busuk akar avokad yang disebabkan oleh $P$. cinnamomi sangat sulit untuk digolongkan dalam model monomolekular (bunga sederhana) atau eksponensial (bunga majemuk).

Berdasarkan hasil uji ketepatan model diketahui bahwa variasi jenis tanah tidak mempengaruhi model perkembangan penyakit. Jenis tanah Ultisol maupun jenis tanah Entisol mempunyai model perkembangan penyakit yang sama yaitu model Gompertz dan model logistik. Variasi penutupan lahanlah yang menentukan dalam perbedaan model perkembangan penyakit (Tabel 3). Model yang tepat untuk perkembangan penyakit busuk pangkal batang lada pada pertanaman lada yang

Tabel 1. Proporsi penyakit busuk pangkal batang lada pada tanah ultisol

\begin{tabular}{ccc}
\hline \multirow{2}{*}{ Pengamatan ke-i } & \multicolumn{2}{c}{ Proporsi Penyakit } \\
\cline { 2 - 3 } & Gulma Sedikit (GS) & Gulma Banyak (GB) \\
\hline 1 & 0,02 & 0,01 \\
2 & 0,03 & 0,02 \\
3 & 0,04 & 0,03 \\
4 & 0,04 & 0,03 \\
5 & 0,10 & 0,06 \\
6 & 0,12 & 0,07 \\
7 & 0,16 & 0,08 \\
8 & 0,18 & 0,09 \\
9 & 0,31 & 0,16 \\
10 & 0,42 & 0,21 \\
11 & 0,55 & 0,25 \\
12 & 0,61 & 0,28 \\
13 & 0,63 & 0,30 \\
14 & 0,66 & 0,31 \\
15 & 0,75 & 0,34 \\
17 & 0,83 & 0,38 \\
\hline
\end{tabular}


Tabel 2. Proporsi penyakit busuk pangkal batang lada pada tanah entisol

\begin{tabular}{ccc}
\hline \multirow{2}{*}{ Pengamatan ke-i } & \multicolumn{2}{c}{ Proporsi Penyakit } \\
\cline { 2 - 3 } & Gulma Sedikit (GS) & Gulma Banyak (GB) \\
\hline 1 & 0,03 & 0,02 \\
2 & 0,04 & 0,02 \\
3 & 0,07 & 0,03 \\
4 & 0,09 & 0,04 \\
5 & 0,10 & 0,05 \\
6 & 0,12 & 0,07 \\
7 & 0,17 & 0,09 \\
8 & 0,25 & 0,11 \\
9 & 0,35 & 0,14 \\
10 & 0,46 & 0,18 \\
11 & 0,58 & 0,23 \\
12 & 0,66 & 0,25 \\
13 & 0,74 & 0,27 \\
14 & 0,81 & 0,30 \\
15 & 0,86 & 0,33 \\
16 & 0,90 & 0,34 \\
17 & 0,95 & 0,39 \\
\hline
\end{tabular}

Tabel 3. Hasil uji ketepatan model perkembangan penyakit busuk pangkal batang lada

\begin{tabular}{|c|c|c|c|c|}
\hline \multirow{2}{*}{ Jenis Tanah } & \multirow{2}{*}{ Parameter } & \multicolumn{3}{|c|}{ Model perkembangan penyakit } \\
\hline & & Logistik & Monomolekular & Gompertz \\
\hline \multirow{6}{*}{ Ultisol } & A. Penutupan gulma sedikit & & & \\
\hline & -Koefisien determinasi, $\mathrm{R}^{2}(\%)$ & 98,80 & 84,60 & 95,60 \\
\hline & -Kuadrat tengah galat (KTG) & 0,05 & 0,08 & 0,06 \\
\hline & B. Penutupan gulma banyak & & & \\
\hline & -Koefisien determinasi, $\mathrm{R}^{2}(\%)$ & 96,40 & 94,50 & 98,30 \\
\hline & -Kuadrat tengah galat (KTG) & 0,06 & 0,02 & 0,05 \\
\hline \multirow{6}{*}{ Entisol } & A. Penutupan gulma sedikit & & & \\
\hline & -Koefisien determinasi, $\mathrm{R}^{2}(\%)$ & 99,00 & 84,20 & 94,10 \\
\hline & -Kuadrat tengah galat (KTG) & 0,04 & 0,15 & 0,11 \\
\hline & B. Penutupan gulma banyak & & & \\
\hline & -Koefisien determinasi, $\mathrm{R}^{2}(\%)$ & 97,30 & 95,50 & 99,50 \\
\hline & -Kuadrat tengah galat (KTG) & 0,04 & 0,001 & 0,001 \\
\hline
\end{tabular}

penutupan gulmanya sedikit adalah Logistik, dan pada yang penutupan gulmanya banyak adalah Gompertz baik pada jenis tanah Ultisol maupun jenis tanah Entisol. Menurut Rivai (2009) model perkembangan penyakit yang disebabkan oleh suatu patogen pada inang tertentu bukanlah hal yang spesifik, artinya penyakit yang telah diidentifikasi perkembangannya menurut model tertentu, dapat saja berubah ke model lain apabila keadaan lingkungan berubah. Kurva model masing-masing variasi lingkungan disajikan pada Gambar 1 dan Gambar 2.

Model perkembangan penyakit busuk pangkal batang lada dalam penelitian ini mengikuti model Gompertz dan Logistik. Perbedaan model ini menggambarkan perbedaan kecepatan perkembangan penyakit busuk pangkal batang lada dan siklus perkembangan patogen. Hal ini menunjukkan bahwa 

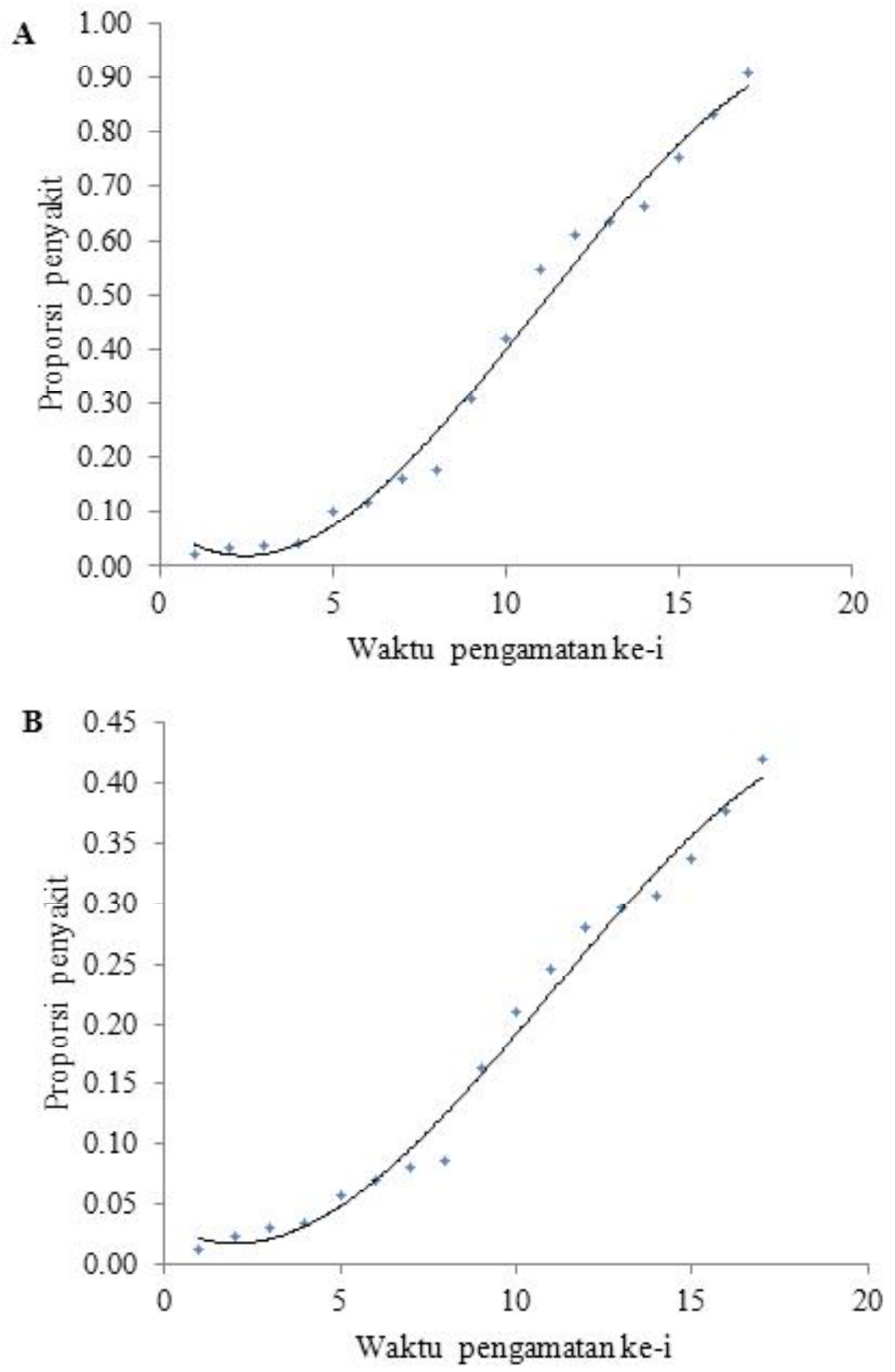

Gambar 1. Kurva model perkembangan penyakit pada jenis tanah Ultisol. (A) model logistik pada penutupan gulmanya sedikit, (B) model Gompertz pada penutupan gulmanya banyak

walaupun patogen penyakit busuk pangkal batang lada di lokasi penelitian (P. capsici) merupakan patogen terbawa tanah (soil borne), tetapi dengan dukungan kondisi lingkungan yang sesuai dapat mempunyai siklus infeksi yang berulang atau tanaman sakit dapat menghasilkan inokulum yang dapat menginfeksi tanaman lada lain di sekitarnya. Hasil inokulasi pada daun, pada kondisi lembap, pada jaringan daun banyak ditemukan sporangium, dan sporangium ini dapat menjadi sumber inokulum baru. Penyakit yang patogennya termasuk soil borne secara teori umumnya hanya mempunyai satu siklus infeksi dalam satu musim atau umur tanaman sehingga model perkembangan penyakitnya digolongkan dalam monomolekular, tetapi dalam penelitian ini patogennya dapat mempunyai lebih dari satu rantai infeksi. Menurut Neher \& Campbell (1992), penyakit busuk akar Phytophthora pada cemara (Abies fraseri) perkembangan penyakitnya termasuk model Gompertz. Dari hasil penelitian Campbell \& Powell (1980 dalam Erwin \& Ribeiro, 1996) diketahui 

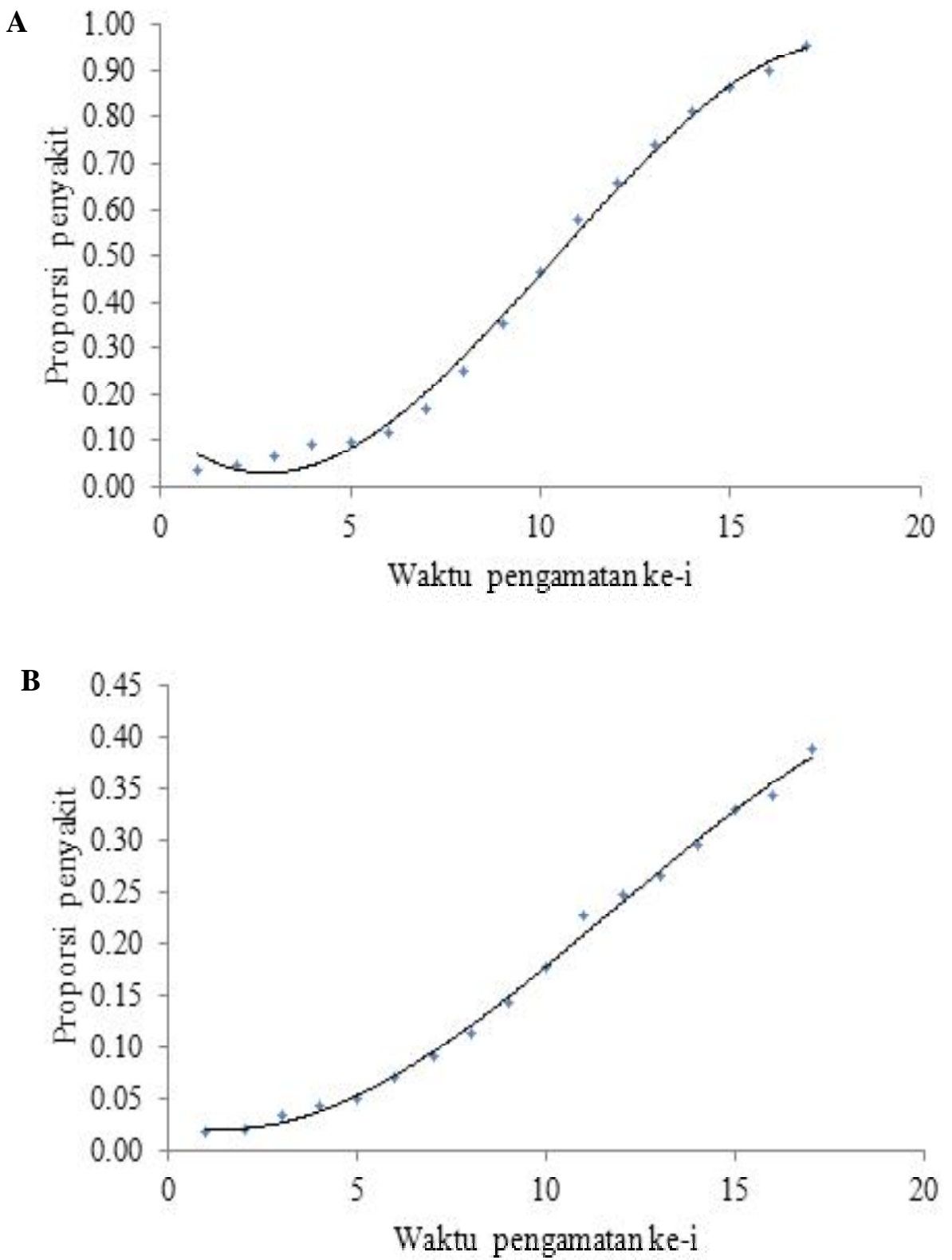

Gambar 2. Kurva model perkembangan penyakit pada jenis tanah Entisol. (A)model logistik pada penutupan gulmanya sedikit, (B) model Gompertz pada penutupan gulmanya banyak.

bahwa sebanyak $84 \%$ penyakit lanas pada tembakau yang disebabkan oleh $P$. parasitica var. nicotianae mengikuti kurva perkembangan eksponensial dan hanya $16 \%$ yang perkembangannya monomolekular. Menurut Campbell (1986), perkembangan penyakit busuk akar sangat beragam, dan khusus pada patogen Phytophthora sp. sebagian besar mengikuti perkembangan bunga majemuk.

Implikasi dari model ini adalah laju infeksi penyakit atau laju perkembangan penyakit (r) busuk pangkal batang lada bervariasi pada tiap lokasi. Dari model perkembangan penyakit tersebut dapat diketahui besarnya nilai laju infeksi penyakit. Kurva model perkembangan penyakit mencirikan nilai dari parameter laju infeksi, intensitas penyakit awal, dan intensitas penyakit maksimum (Rivai, 2009). Menurut Neher et al. (1997), model dapat digunakan sebagai alat pembanding dalam kurva perkembangan penyakit. Model perkembangan penyakit pada model logistik dan model Gompertz mempunyai kurva berbentuk sigmoid 
(S) yang berarti pada awal infeksi perkembangan penyakit berjalan lambat, kemudian meningkat secara cepat, dan selanjutnya melambat kembali (Gambar 1 dan Gambar 2). Model perkembangan penyakit ini selanjutnya digunakan untuk mengetahui laju perkembangan penyakit busuk pangkal batang lada pada masing-masing lokasi penelitian.

Laju infeksi penyakit fluktuatif selama periode pengamatan dan berbeda pada masing-masing lokasi. Hasil perhitungan laju infeksi menunjukkan bahwa jenis tanah yang berbeda mempengaruhi laju infeksi penyakit busuk pangkal batang lada yang berbeda. Laju infeksi pada pertanaman lada pada tanah Ultisol baik pada kebun yang gulmanya sedikit maupun pada kebun yang penutupan gulmanya banyak lebih rendah dibandingkan dengan jenis tanah Entisol (Tabel 2). Tanah Entisol mempunyai perkembangan penyakit yang lebih tinggi diduga karena mempunyai tingkat kesuburan yang lebih rendah. Hasil analisis tanah menunjukkan bahwa nilai unsur makro (N, P, K, dan bahan organik) pada tanah Ultisol lebih tinggi dibandingkan jenis tanah Entisol. Lada yang ditanam di daerah yang kurang sesuai untuk lada, akan mudah mendapat gangguan hama dan penyakit. Infeksi patogen akan meningkat pada tanah yang kekurangan unsur hara terutama kalium dan fosfat (Hadiwiyono \& Widono, 2008). Perkembangan penyakit bersifat spesifik untuk tiap-tiap penyakit tanaman yang sangat dipengaruhi oleh lingkungan sekitarnya sehingga dapat berubah apabila lingkungan sekitar populasi tanaman berubah (Rivai, 2009). Menurut Hadisutrisno (1989), semakin tinggi laju infeksi, maka semakin pendek periode perkembangan penyakit sehingga epidemi semakin cepat terjadi.

Berdasarkan kondisi pertanaman lada, perkembangan penyakit pada pertanaman lada yang penutupan gulmanya banyak mempunyai laju infeksi yang lebih rendah dibandingkan dengan pertanaman lada yang penutupan gulmanya sedikit (Tabel 4). Hal ini menunjukkan bahwa gulma yang banyak dapat menurunkan laju perkembangan penyakit. Gulma dapat menghambat aliran air permukaan (run-off surface) yang dapat membawa inokulum patogen dalam pertanaman lada sehingga inokulum patogen tidak menyebar ke tanaman sehat di sekitarnya selama musim hujan dan juga gulma di sekitar tanaman lada dapat menjadikan suasana kondusif tempat hidup bagi mikroorganisme antagonistik. Menurut Wahyuno (2009), patogen penyakit busuk pangkal batang lada mudah terbawa air, tanah, atau bagian tanaman yang terserang sehingga penanaman tanaman penutup tanah dapat mengurangi penyebaran inokulum $P$. capsici dari tanaman sakit ke tanaman sehat di sekitarnya.

Tingginya laju infeksi penyakit busuk pangkal batang lada juga ditentukan oleh penularan P. capsici di lapangan. Keberadaan gulma atau tanaman penutup tanah diduga berperan dalam menghambat pergerakan inokulum $P$. capsici dari dalam tanah untuk sampai ke tanaman lada sehat. Inokulum dari P. capsici yang terbawa oleh agen tertentu atau pergerakan secara aktif sampai pada tanaman lada akan mengadakan kontak dengan tanaman lada sehingga terjadi penularan (inokulasi). Berbagai cara penularan P. capsici terutama melalui bantuan air yakni aliran air pada permukaan tanah membawa inokulum $P$. capcisi (hifa, sporangium, zoospora dan oospora), pergerakan kapiler air tanah yang membawa inokulum, partikel tanah yang telah terkontaminasi (Hausbeck \& Lamour, 2004; Granke et al., 2009) dan penularan melalui angin sangat kecil terjadi (Granke et al., 2009). Penularan juga dapat melalui tetesan air hujan yang jatuh ke tanah dapat membantu memindahkan inokulum dari tanah ke daun yang di dekatnya sehingga memungkinkan terjadinya infeksi $P$. capsici, alat pertanian yang telah terkontaminasi, bibit lada sakit, keong/siput, dan terbawa oleh ternak peliharaan (Manohara et al., 2005) serta bagian tanaman yang terserang (Wahyuno, 2009). Penularan secara aktif melalui pergerakan zoospora yang mampu berenang dalam air pada saluran drainase atau saat hujan menuju akar tanaman (Hausbeck \& Lamour, 2004; Wahyuno, 2009).

Tabel 4. Laju infeksi (r) penyakit busuk pangkal batang lada pada berbagai variasi lingkungan

\begin{tabular}{ccc}
\hline Jenis Tanah & Penutupan Gulma & $\begin{array}{c}\text { Laju Infeksi (r) } \\
\text { (per unit per hari) }\end{array}$ \\
\hline \multirow{2}{*}{ Ultisol } & Sedikit & 0,188 \\
& Banyak & 0,050 \\
\multirow{2}{*}{ Entisol } & Sedikit & 0,200 \\
& Banyak & 0,133 \\
\hline
\end{tabular}




\section{SIMPULAN}

Jenis tanah tidak mempengaruhi model perkembangan penyakit busuk pangkal batang lada tetapi mempengaruhi laju infeksi penyakit. Model perkembangan penyakit busuk pangkal batang lada pada pertanaman lada yang penutupan gulmanya banyak adalah Gompertz dan pada penutupan gulmanya sedikit adalah Logistik. Laju infeksi penyakit busuk pangkal batang lada lebih rendah pada jenis tanah Ultisol dibanding pada tanah Entisol. Pertanaman lada yang gulmanya banyak mempunyai laju infeksi (r) yang lebih rendah dibandingkan dengan pertanaman lada yang gulmanya sedikit.

\section{DAFTAR PUSTAKA}

Balittri (Balai Penelitian Tanaman Rempah dan Aneka Tanaman Industri). 2009. Prospek dan Arah Pengembangan Agribisnis Lada. http:// ballitri.litbang.deptan.go.id/database/unggulan/ propeklada.pdf. Diakses tanggal 4 Agustus 2009.

Bande LOS, Hadisutrisno B, Somowiyarjo S, \& Sunarminto BH. 2011. Karakteristik Phytophthora capsici isolat Provinsi Sulawesi Tenggara. Agriplus 21(01): 75-82.

Benson DM, Grand LF, \& Vernia CS. 2006. Temporal and Spatial Epidemiology of Phytophthora Root Rot in Fraser Fir Plantations. Plant Dis. 90(9): 1171-1180.

Berger RD. 1981. Comparasion of the Gompertz and Logistic equations to describe plant disease progress. Phytopathology 71(7): 716-719.

Campbell CL, Jacobi WR, Powell NT, \& Main CE. 1984. Analysis of disease progression and the randomness of occurrence of infected plants during tobacco black shank epidemics. Phytopathology 74(2): 230-235.

Campbell CL. 1986. Interpretation and uses of disease progress curves for root diseases. In: Leonard KJ \& Fry WE (Eds.). Plant Disease Epidemiology. Population Dynamics and Management. Vol. 1. pp. 38-54. Macmillan Publishing Company. New York \& Collier Macmillan Publishers, London.
Erwin DC \& Ribeiro OK. 1996. Phytophthora Disease Worldwide. The American Phytopathological Society. Minnesota. USA.

Granke LL, Windstam ST, Hoch HC, SmartCD, \& Hausbeck MK. 2009. Dispersal and movement mechanisms of Phtophthora capsici sporangia. Phytopathology 99(11): 1258-1264.

Hadisutrisno B. 1989. Kajian epidemi penyakit hawar daun phoma pada tanaman serat-seratan. Dalam: Dwidjaputra IGP, Westen N, \& Oka IB (Eds.). Prosiding Kongres Nasional X dan Seminar Ilmiah PFI: Meningkatkan Peranan Perhimpunan Fitopatologi Indonesia Menuju Pertanian yang Maju, Efisien dan Tangguh. pp. 331-334. Denpasar. 14-16 Desember 1989.

Hadiwiyono \& Widono S. 2008. Hubungan faktor lingkungan tanah terhadap intensitas busuk pangkal bawang putih di Tawangmangu. Agrin 12(1): 15-22.

Hausbeck MK \& Lamour KH. 2004. Phytophthora capsici on vegetable crops: research progress and management challenges. Plant Dis. 88(12): 1292-1303.

MacKenzie DR, Elliott VJ, Kidney BA, King ED, \& Royer MH. 1983. Application of modern approaches to the study of the epidemiology of diseases caused by Phytophthora (plant pathogens). In: Erwin DC, Bartnicki-Garcia S, \& Tsao PH. (Eds.). Phytophthora its Boilogy, Taxonomy, Ecology, and Pathology. pp: 303313. The American Phytopathological Society. Minnesota. USA.

Manohara D, Wahyuno D, \& Noveriza R. 2005. Penyakit busuk pangkal batang tanaman lada dan strategi pengendaliannya. Perkembangan Teknologi Tanaman Rempah dan Obat 17: 4151.

Milgroom MG \& Peever TL. 2003. Population biology of plant pathogens: the synthesis of plant disease epidemiology and population genetics. Plant Dis. 87(6): 608-617.

Neher DA \& Campbell CL. 1992. Underestimation of disease progress rates with the logistic, monomolecular, and gompertz models when maximum disease intensity is less than 100 percent. Phytopathology 82(8): 811-814. 
Neher DA, Reynolds KL, \& Campbell CL. 1997. Analysis of disease progress curves using liniear models. In: Francl LJ \& Neher DA (Eds.). Exercises in Plant Disease Epidemiology. pp. 29-33. The American Phytopathological Society. Minnesota. USA.

Rivai F. 2009. Dimensi Waktu dan Ruang Penyakit Tumbuhan. Universitas Baiturrahmah. Padang.
Wahyuno D. 2009. Pengendalian Terpadu Busuk Pangkal Batang Lada. Perspektif 8(1): 17-29.

Yuhono JT. 2007. Sistem agribisnis lada dan strategi pengembangannya. J. Litbang Pertanian 26(2): 76-81.

Zadoks JC \& Schein RD. 1979. Epidemiology and Plant Disease Management. Oxford University Press. New York. 